\title{
Interrelationships Between Physical State, Phenotypic Stability and Transferability of $\beta$-Lactamase Genes in Haemophilus influenzae
}

\author{
By JOHN E. WILLARD, ${ }^{1}$ EMMETT J. JOHNSON ${ }^{2}$ AND \\ ROBERT S. DAUM ${ }^{1 *}$ \\ Departments of Paediatrics ${ }^{1}$ and Microbiology and Immunology ${ }^{2}, 1430$ Tulane Avenue, \\ Tulane University School of Medicine, New Orleans, Louisiana 70112, U.S.A.
}

(Received 2 December 1981; revised 22 February 1982)

\begin{abstract}
We have evaluated $66 \beta$-lactamase-producing $\left(\beta\right.$-Lac $\left.{ }^{+}\right)$clinical isolates of Haemophilus influen$z a e$ for the presence of plasmid DNA, ability to conjugate with an $H$. influenzae type b recipient,

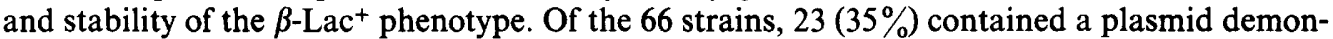
strable by either of two methods of cleared cell lysate preparation. The molecular weight of 17 of the plasmids was approximately $30 \times 10^{6}$. Four strains carried a plasmid of mol. wt $3 \times 10^{6}$ and single strains carried plasmids of mol. wt $36 \times 10^{6}$ or $50 \times 10^{6}$. Of 23 plasmids that were unstable in vitro, $10(43 \%)$ had molecular weights of $30 \times 10^{6}$ and coded only for $\beta$-lactamase. Stability of the $\beta$-Lac ${ }^{+}$phenotype was observed in all 43 strains in which plasmid DNA was not demonstrated by physical methods. When $\beta$-Lac ${ }^{+}$, 'plasmid-free' strains were conjugated with strain Eagan ( $H$. influenzae type b), ampicillin-resistant transconjugants were isolated in 21 out of 43 matings (the lower limit of detection was $10^{-7}$ per donor cell per 30 min mating). With few exceptions, homologous (type $\mathrm{b} \times$ type $\mathrm{b}$ ) crosses with $\beta$-Lac ${ }^{+}$, plasmid-containing donors were more efficient (frequency $10^{-2}-10^{-3}$ ) than heterologous (untypable $\times$ type b) matings (frequency $10^{-6}-10^{-7}$ ). $\beta$-Lac ${ }^{+}$, 'plasmid-free' strains were inefficient donors (frequency $10^{-6}-10^{-7}$ ) irrespective of serotype, but all transconjugants from these crosses were efficient donors (frequency $\left.10^{-1}-10^{-4}\right)$ and contained a plasmid of mol. wt $30 \times 10^{6}$ that was unstable in 9 cases out of $26(35 \%)$. The increase in transferability and phenotypic instability of plasmid-bearing $\beta$ $\mathrm{Lac}^{+}$strains reinforces the concept of a chromosomal locus for $\beta$-lactamase genes in 'plasmidfree' $\beta$-Lac ${ }^{+}$strains. Carriage of $\beta$-lactamase genes on $30 \times 10^{6} \mathrm{~mol}$. wt $\mathbf{R}$ plasmids aids transferability at the expense of genetic stability.
\end{abstract}

\section{INTRODUCTION}

Ampicillin resistance in Haemophilus influenzae, first observed by Gunn et al. (1974), is usually associated with the constitutive production of a $\beta$-lactamase; identified as TEM or type IIIa (Farrar \& O'Dell, 1974; Laufs et al., 1979; Medeiros \& O'Brien, 1975; Saunders et al., 1978; Sykes et al., 1975; Vega et al., 1976). This enzyme is specified by the transposable genetic element TnA (Hedges \& Jacob, 1974; Heffron et al., 1975a; Jahn et al., 1979; Laufs \& Fock, 1979; Saunders \& Sykes, 1977) and is found on many phylogenetically distinct plasmids which reside in Gram-negative bacteria (Heffron et al., 1975b).

The genes that code for $\beta$-lactamase production in $H$. influenzae (phenotype $\beta$-Lac ${ }^{+}$) were identified on plasmids of molecular weight $3 \times 10^{6}$ or $30 \times 10^{6}$ (DeGraaff et al., 1976; Elwell et al., 1975, 1977; Laufs \& Kaulfers, 1977; Laufs et al., 1979). Ampicillin resistant (Ap $\left.{ }^{\mathrm{R}}\right) H$. influenzae strains that produced $\beta$-lactamase but lacked demonstrable $\mathbf{R}$ plasmids were described by Slaney \& Albritton (1979); Stuy $(1979,1980)$; and Roberts \& Smith (1980). However, these investigators demonstrated $R$ plasmids in transconjugants from matings between $A p^{R}$ 'plasmid-free' donors and a rough, non-irridescent recipient derived from a strain of $H$. influenzae type d (Rd) (Alexander \& Leidy, 1953). Roberts \& Smith (1980) compared two methods for 
the isolation of covalently closed circular DNA (Hansen \& Olsen, 1978; Meyers et al., 1976) from $H$. influenzae isolates possessing various resistance patterns. The inclusion of a second method did increase their ability to demonstrate $\mathbf{R}$ plasmids, but they were unable to demonstrate plasmid DNA in $41 \%$ ( 9 out of 22 ) of the strains. Slaney \& Albritton (1979) suggested that 'host factors' indigenous to the strain determined the physical state of antibiotic resistance plasmids in $H$. influenzae. More specifically, Stuy (1980) suggested that these 'plasmid-free' strains carried their $\beta$-lactamase genes on a chromosomally integrated plasmid.

Chromosomal integration of an $\mathrm{R}$ plasmid might be expected to affect both the stability and dissemination of the phenotype. We have reported spontaneous loss of ampicillin resistance in vitro from two $H$. influenzae type b strains, both of which possessed plasmids of mol. wt $30 \times 10^{6}$, and suggested that in such strains the $\beta$-Lac ${ }^{+}$phenotype was unstable (Daum et al., 1981). In contrast, an $\mathrm{Ap}^{\mathrm{R}} H$. influenzae type b strain that uniformly maintained its $\beta$-Lac ${ }^{+}$phenotype in vitro was subsequently shown to lack extrachromosomal DNA. Inoculation of infant Macaca mulatta with either of the two $H$. influenzae type $\mathrm{b} \mathrm{Ap}^{\mathrm{R}}$ isolates containing plasmids resulted in the isolation of only $\beta$ - $\mathrm{Lac}^{-}$bacteria from the blood and cerebrospinal fluid (CSF). In contrast, inoculation with the phenotypically stable strain resulted in isolation of uniformly $\beta$-Lac ${ }^{+}$ bacteria from blood and CSF (Daum et al., 1981). The correlation between the presence of plasmid DNA and phenotypic stability in vitro and in vivo documented in these three $\operatorname{Ap}^{\mathrm{R}} H$. influenzae type $\mathrm{b}$ strains prompted an investigation into the relationships between these phenomena.

In this report, we (1) assess the prevalence of $\mathrm{Ap}^{\mathrm{R}} H$. influenzae isolates that have demonstrable $\mathrm{R}$ plasmids, and the stability of the $\beta$-Lac ${ }^{+}$phenotype; (2) compare conjugational transfer frequencies between plasmid-containing and 'plasmid-free' donors and an $H$. influenzae type b recipient; (3) examine transconjugants for plasmid DNA and their phenotypic stability; and (4) consider the evolutionary significance of the mobility of genetic determinants of ampicillin resistance in $H$. influenzae.

\section{METHODS}

Bacteria. A total of 66 clinical $H$. influenzae isolates resistant to ampicillin were obtained for study. The source, serotype, phenotype, and site of isolation of these strains are listed in Tables 1 and 2. Strain Eagan (E), a well characterized $\mathrm{Ap}^{\mathrm{S}}$ H. influenzae type b strain (Anderson et al., 1972), was used in matings. All $H$. influenzae strains were identified by standard criteria (Morse, 1980), serotyped with $H$. influenzae antisera (Difco), and assessed for $\beta$-lactamase production by chromogenic cephalosporin hydrolysis (O'Callaghan et al., 1972). Stock cultures were maintained in skim milk at $-70^{\circ} \mathrm{C}$.

Resistant mutants. For the purposes of conjugation experiments, a streptomycin-resistant $\left(\mathrm{Str}^{\mathrm{R}}\right)$ mutant of wildtype strain $\mathrm{E}$ was obtained as described previously (Moxon et al., 1974). This strain was made rifampin resistant $\left(\mathrm{Rif}^{\mathrm{R}}\right.$ ) by growing it overnight in Brain Heart Infusion broth supplemented with horse erythrocyte lysate and $\beta$ nicotinamide adenine dinucleotide (BHIs). A sample of approximately $10^{10}$ c.f.u. was then plated on BHIs agar that contained rifampin $\left(2 \mu \mathrm{g} \mathrm{ml}^{-1}\right)$. The frequency of spontaneous mutant isolation was $1.2 \times 10^{-9}$ per $\mathrm{E}$ c.f.u. for $E \operatorname{Str}^{\mathrm{R}}$ and $3.4 \times 10^{-9}$ per $\mathrm{E} \mathrm{Str}{ }^{\mathrm{R}}$ c.f.u. for $\mathrm{E} \mathrm{Str}^{\mathrm{R}} \mathbf{R i f}^{\mathrm{R}}$. The minimum inhibitory concentration (m.i.c.) of streptomycin exceeded $500 \mu \mathrm{g} \mathrm{ml}^{-1}$ for both strains while the m.i.c. of rifampin was $<0.5 \mu \mathrm{g} \mathrm{ml}^{-1}$ and $>2.0 \mu \mathrm{g}$ $\mathrm{ml}^{-1}$ for $\mathrm{E} \mathrm{Str}{ }^{\mathrm{R}}$ and $\mathrm{E} \mathrm{Str}{ }^{\mathrm{R}} \mathrm{Rif}^{\mathrm{R}}$, respectively.

Plasmid stability. Isolated colonies plated on solid medium from $18 \mathrm{~h}$ broth cultures were assayed for $\beta$-lactamase production by hydrolysis of penicillin G (Lilly, Indianapolis, Indiana, U.S.A.) as indicated by water-soluble phenol red (Sigma) (Daum et al., 1981). A minimum of 1000 colonies was examined for each strain.

Conjugation experiments. Broth cultures $\left(15 \mathrm{~h}\right.$ ) of donor (approx. $10^{9} \mathrm{c.f} . \mathrm{u} . \mathrm{ml}^{-1}$ ) and recipient bacteria were prepared in BHIs broth. $\mathrm{MgSO}_{4}$ (1 mM final concentration) was added to $1.0 \mathrm{ml}$ broth containing recipient cells and the mixture vortexed vigorously for $20 \mathrm{~s}$. A $0.1 \mathrm{ml}$ sample of the donor strain suspension (approx. $10^{8}$ c.f.u.) was then added and the mixture was filtered through a Metricel filter (type GA-6, pore size $0.45 \mu \mathrm{m}$ ) (Gelman Instrument Co., Ann Arbor, Michigan, U.S.A.). The filter was incubated $\left(30 \mathrm{~min}, 5 \% \mathrm{CO}_{2}, 38^{\circ} \mathrm{C}\right)$ on the surface of a fresh, antibiotic-free BHIs agar plate. Cells were recovered by vigorous agitation of the filter in $4.0 \mathrm{ml}$ phosphate-buffered saline and plated on to selective BHIs agar containing appropriate combinations of streptomycin $\left(500 \mu \mathrm{g} \mathrm{ml}^{-1}\right)$, ampicillin $\left(2 \mu \mathrm{g} \mathrm{ml}^{-1}\right)$ and/or rifampin $\left(2 \mu \mathrm{g} \mathrm{ml}^{-1}\right)$. Antibiotic-resistant phenotypes were scored after $18-24 \mathrm{~h}$ incubation at $37^{\circ} \mathrm{C}$. For overnight matings, the filters were allowed to incubate for about $18 \mathrm{~h}$ before bacteria were washed from the filters and plated. The inclusion of DNAase (type I, calf thymus, Sigma) (Laufs \& Fock, 1979) during matings did not affect the observed transfer frequencies. The lower limit of 
transconjugant detection for 30 min matings was $10^{-7}$ c.f.u. per donor cell. All $66 \mathrm{Ap}^{\mathrm{R}} \mathrm{H}$. influenzae strains were mated with the $H$. influenzae type $\mathrm{b} \mathrm{E} \mathrm{Str}^{\mathrm{R}}$ recipient for $30 \mathrm{~min}$. The $10 \mathrm{Ap}^{\mathrm{R}} H$. influenzae strains that did not mate with $E \operatorname{Str}^{R}$ in 30 min were mated with $E \operatorname{Str}^{R}$ overnight. Transconjugant strains, when isolated, were verified as $\mathrm{Ap}^{\mathrm{R}} H$. influenzae type $\mathrm{b}$ and mated with the $\mathrm{E} \mathrm{Str}^{\mathrm{R}} \mathrm{Rif}^{\mathrm{R}}$ recipient.

Plasmid DNA preparation and agarose gel electrophoresis. Cleared cell lysates from all $66 \mathrm{Ap}^{R} H$. influenzae strains were prepared by acid phenol extraction (Daum et al., 1981); 24 of these strains were also lysed with SDS in an alkaline denaturation technique of plasmid isolation (Hansen \& Olsen, 1978). Electrophoresis conditions were as previously described (Daum et al., 1981). The approximate molecular weight of each plasmid was determined from its migration distance in agarose gels relative to the migration distance of plasmids of molecular weights ranging from $2.6 \times 10^{6}$ to $36 \times 10^{6}$ (Broda, 1979).

\section{RESULTS}

Serotype of $A p^{\mathrm{R}}$ clinical isolates. Of the $66 \mathrm{H}$. influenzae strains examined, $37(56 \%)$ belonged to serotype $b$ and $26(39 \%)$ were untypable. Two strains were of serotype $d$ and there was one type $c$ isolate (Tables 1 and 2).

Presence of $R$ plasmids in wild-type strains. All 66 clinical $H$. influenzae $\mathrm{Ap}^{\mathrm{R}}$ isolates and recipient strain $\mathrm{E}$ were screened for the presence of plasmid DNA by agarose gel electrophoresis of cleared lysates prepared by acid phenol extraction. Plasmid DNA was demonstrated in 23 strains, of which 10 were of serotype $b$ (Table 1). Plasmid DNA was not found in the strain $E$, E Str ${ }^{\mathrm{R}}$ or $\mathrm{E} \mathrm{Str}{ }^{\mathrm{R}} \mathrm{Rif}^{\mathrm{R}}$.

The molecular weights of the 23 plasmids isolated were approximately $30 \times 10^{6}$ in 17 cases (16 $\mathrm{Ap}^{\mathrm{R}}$ phenotype and one $\mathrm{Ap}^{\mathrm{R}} \mathrm{Tc}^{\mathrm{R}}$ phenotype), $3 \times 10^{6}$ in four cases (all $\mathrm{Ap}^{\mathrm{R}}$ phenotype), 36 $\times 10^{6}$ in one case $\left(\mathrm{Ap}^{\mathrm{R}} \mathrm{Cm}^{\mathrm{R}} \mathrm{Tc}^{\mathrm{R}}\right.$ phenotype), and $50 \times 10^{6}$ in one case $\left(\mathrm{Ap}^{\mathrm{R}} \mathrm{Cm}^{\mathrm{R}} \mathrm{Tc}^{\mathrm{R}}\right.$ phenotype).

To determine whether a second technique of lysis might reveal plasmid DNA in any of the 43 remaining isolates, 22 strains designated 'plasmid-free' by acid phenol extraction were examined by the method of Hansen \& Olsen (1978). This technique demonstrated plasmid DNA in R724 (Table 1) and in two positive control strains shown to possess plasmid DNA by acid phenol extraction.

Conjugational transfers. Almost all $\mathrm{b} \times \mathrm{b}$ crosses $\left(\mathrm{E} \mathrm{Str}{ }^{\mathrm{R}}\right.$ recipient) in which the donor contained demonstrable plasmid DNA resulted in transconjugant isolation in 30 min matings, the exception being when the donor contained non-conjugative plasmids of mol. wt $3 \times 10^{6}$. In contrast, transconjugants were isolated from 6 out of 13 non-b $\times$ b matings in which the donors contained demonstrable plasmids. The seven non-b donor strains whose resistance determinants did not transfer in $30 \mathrm{~min}$ did transfer resistance determinants following overnight mating (with the exception of two strains with plasmids of mol. wt $3 \times 10^{6}$ ).

Of 43 'plasmid-free' strains, $21(49 \%)$ transferred their resistance to $\mathrm{E} \mathrm{Str}^{\mathrm{R}}$ in 30 min matings. Ten strains which did not transfer (two type b, one type c, one type d, and six untypable) were chosen for overnight mating. All ten matings resulted in the isolation of a transconjugant strain.

Transconjugants derived from matings with 'plasmid-free' donors, including those isolated after overnight mating only, were evaluated for the presence of plasmid DNA. All such strains had plasmids demonstrable by acid phenol extraction. The molecular weights of plasmids identified in each transconjugant uniformly approximated $30 \times 10^{6}$.

Haemophilus influenzae type b strains carrying demonstrable plasmid DNA transferred at significantly higher frequencies $\left(10^{-2}-10^{-3}\right)$ than did 'plasmid-free' donors $\left(10^{-6}-10^{-7}\right)(P<$ $0.001, t$-test of geometric means). Exceptions included three $H$. influenzae type b strains with plasmid DNA that transferred at a frequency of $10^{-5}$, two of which were multiply resistant $\left(\mathrm{Ap}^{\mathrm{R}} \mathrm{Cm}^{\mathrm{R}} \mathrm{Tc}^{\mathrm{R}}\right)$; two 'plasmid-free' strains also transferred at $10^{-5}$. All type $b$ transconjugants, irrespective of the presence of demonstrable plasmid DNA in their donors, were themselves efficient donors and transferred their resistance at frequencies of $10^{-1}-10^{-4}$ during $30 \mathrm{~min}$ matings with E Str ${ }^{\mathrm{R}}$ Rif $^{\mathrm{R}}$.

Untypable $H$. influenzae strains, irrespective of demonstrable plasmid presence, transferred to $\mathrm{E} \mathrm{Str}{ }^{\mathrm{R}}$ at a frequency of $10^{-6}-10^{-7}$. (Two untypable $H$. influenzae strains with $30 \times 10^{6} \mathrm{~mol}$. 


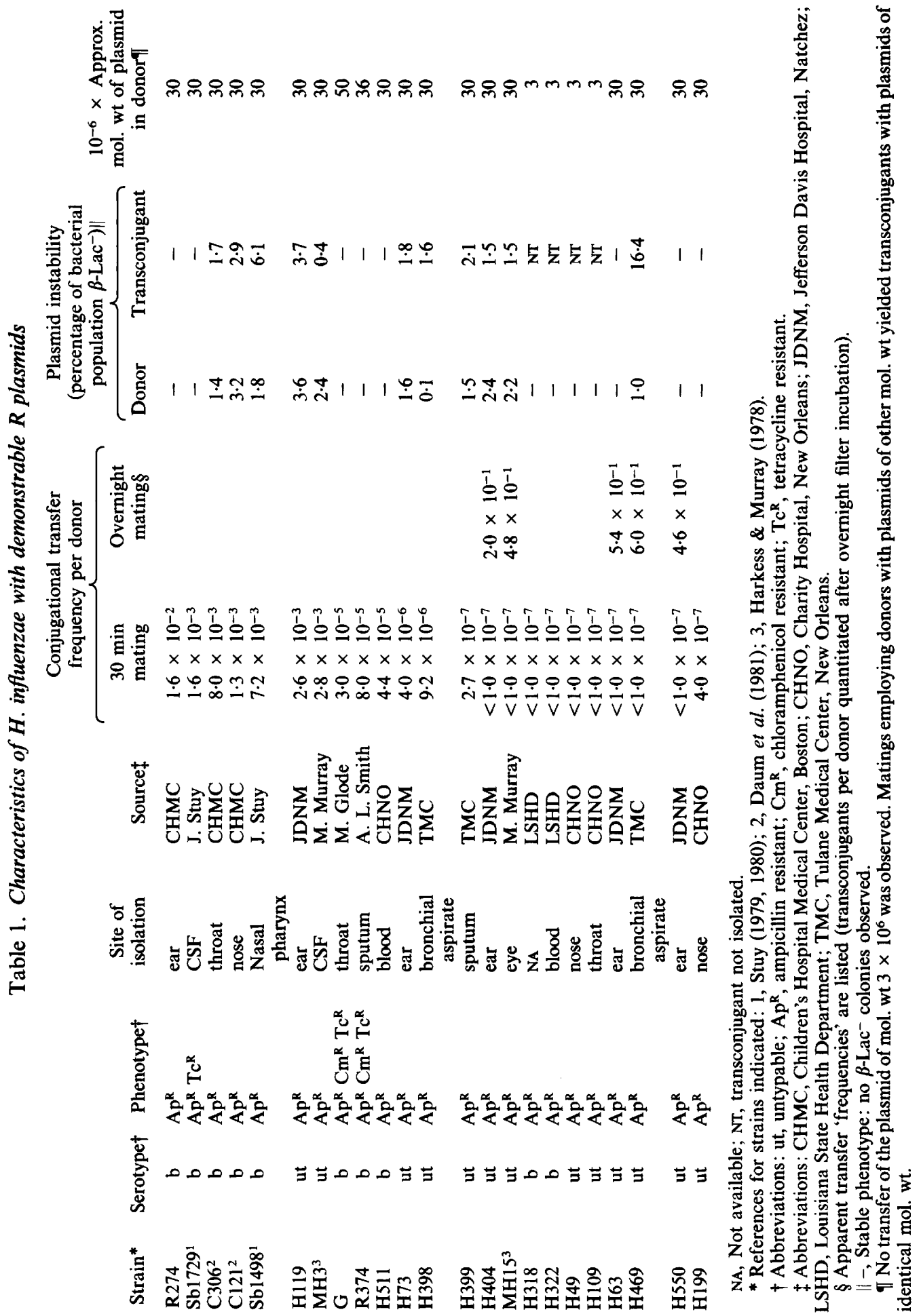




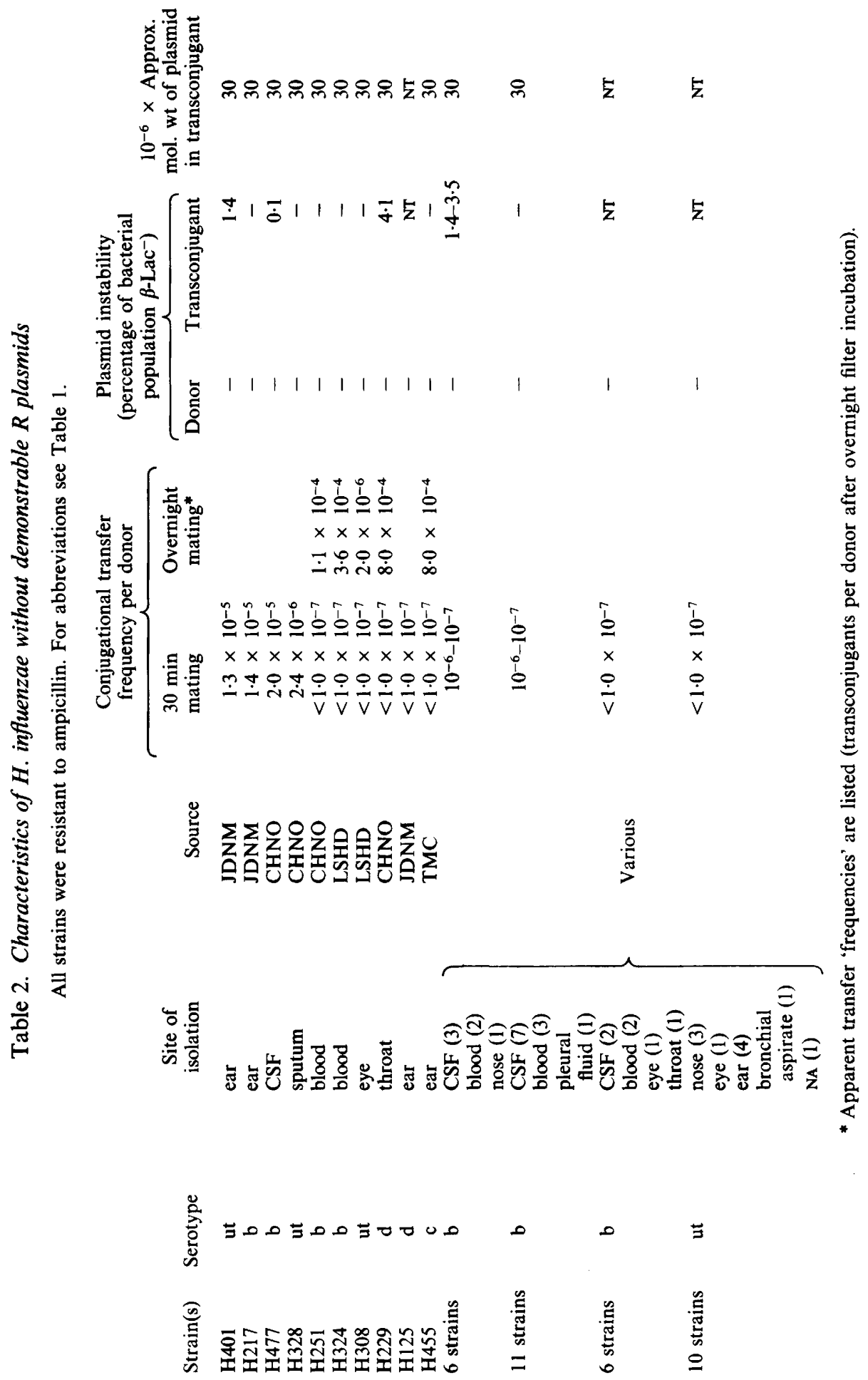


wt $\mathrm{R}$ plasmids that transferred at a frequency of $10^{-3}$ and one strain lacking a demonstrable plasmid that transferred at a frequency of $10^{-5}$, were exceptions.)

The transfer frequencies for the ten matings which were allowed to continue overnight ranged from $10^{-1}$ to $10^{-6}$ transconjugants per donor.

Plasmid stability. A mean of 1500 colonies from each strain was examined for the absence of $\beta$ lactamase production. The proportion of the bacterial population of a given strain that did not produce $\beta$-lactamase ranged from 0 to $16.4 \%$ (Tables 1 and 2 ). Instability of the $\beta$-Lac ${ }^{+}$phenotype was evident in 10 out of 23 strains that possessed demonstrable plasmids. All 10 plasmids were of mol. wt. $30 \times 10^{6}$ and none coded for multiple drug resistance. Significantly, the transconjugants of all 10 unstable strains also exhibited phenotypic instability.

All $43 \mathrm{Ap}^{\mathrm{R}} H$. influenzae strains lacking demonstrable plasmid DNA were phenotypically stable. However, $35 \%$ (9 out of 26 ) of their transconjugants, including one of five isolated from overnight mating, demonstrated phenotypic instability. All strains demonstrating instability, whether clinical isolates or transconjugants, contained plasmid DNA of mol. wt $30 \times 10^{6}$.

\section{DISCUSSION}

We selected the Eagan strain as the recipient because of the clinical importance of $\mathrm{R}$ plasmid acquisition by $H$. influenzae type b strains. Plasmid DNA is demonstrable in transconjugants produced by 'plasmid-free' strains crosses with Rd recipients (Slaney \& Albritton 1979; Stuy 1979, 1980; Roberts \& Smith 1980). Our data confirm that the majority $(65 \%)$ of $\mathrm{Ap}^{\mathrm{R}} H$. influenzae clinical isolates are 'plasmid-free' but transfer their resistance to $H$. influenzae type b strain $\mathrm{E} \mathrm{Str}{ }^{\mathrm{R}}$. The resulting transconjugants invariably contain demonstrable plasmid DNA.

Roberts \& Smith (1980) performed overnight filter matings with a serotype b or untypable $H$. influenzae donor and an $\mathrm{Rd}$ recipient. Identical transfer frequencies were observed irrespective of donor serotype, or the presence of demonstrable plasmid DNA in the donor. The transfer frequencies we observed following 30 min matings were significantly different $(P<0.001)$ if 'plasmid-free' $\left(10^{-6}-10^{-7}\right)$ and plasmid-carrying donors $\left(10^{-1}-10^{-4}\right)$ were compared. Moreover, transfer between strains of identical serotype $(b \times b)$ is more efficient than that between strains of different serotypes (non-b $\times b$ ). This difference is not apparent when these matings are allowed to continue overnight (data not shown). Since Rd transconjugants are themselves efficient donors and rapidly pass on plasmid DNA to other susceptible Rd cells (Stuy, 1980), the prolonged mating time increases the apparent 'frequency' of resistance transfer.

Roberts \& Smith (1980) showed that preparation of cleared cell lysates by an alternative method (Hansen \& Olsen, 1978) allowed the isolation of plasmid DNA from some 'plasmid-free' strains. However, we identified an R plasmid in only one strain (R274) designated 'plasmid-free' by acid phenol extraction. We had anticipated an extrachromosomal resistance determinant in this strain since, among those $\mathrm{Ap}^{\mathrm{R}}$ isolates classed as 'plasmid-free' by the acid phenol technique, it uniquely transferred its resistance to $\mathrm{E} \mathrm{Str}{ }^{\mathrm{R}}$ at high frequency $\left(10^{-2}\right)$ and could be cured by acridine orange (data not shown).

Hypotheses advanced by others to explain 'plasmid-free' antibiotic resistant $H$. influenzae include the following: (1) damage of extrachromosomal DNA during lysing procedures resulting in the loss of plasmid DNA, or alterations in plasmid mobility resulting in co-migration of plasmid DNA with chromosomal DNA (Roberts \& Smith, 1980); (2) insertion of resistance determinants directly into the chromosome (Bendler, 1976); and (3) integration of the entire $\mathbf{R}$ plasmid into the chromosome (Stuy, 1980).

Our data support the concept of chromosomally integrated R plasmids (Stuy, 1980) rather than differences in lysing techniques (Roberts \& Smith, 1980), for the absence of demonstrable $\mathrm{R}$ plasmids in most $\mathrm{Ap}^{\mathrm{R}} H$. influenzae 'plasmid-free' isolates. Evidence for this conclusion includes: (1) the fact that an increase in transferability of resistance is observed when the 'plasmid-free' donor and its plasmid containing transconjugant are compared; (2) transconjugants of $\mathrm{R}$ plasmid-bearing donors mimic the plasmid instability of their donor, indicating that loss of ampicillin resistance in vitro is a plasmid function rather than a cell function; (3) 'plasmid- 
free' donors are $100 \%$ (43 out of 43 ) phenotypically homogeneous, while only $65 \%$ (17 out of 26$)$ of their respective plasmid-containing transconjugants are phenotypically homogeneous; and (4) all transconjugants have demonstrable R plasmids. We do not know whether transfer of the integrated plasmid occurs by chromosome mobilization or by excision followed by transfer. However, the former seems less likely since Stuy (1980) has provided evidence that transformants from strains without demonstrable $\mathrm{R}$ plasmids transfer resistance to an $\mathrm{Rd}$ rec $A$ recipient. This suggests a low frequency excision rate resulting in extrachromosomal DNA capable of conjugal transfer.

The existence of two modes of $\mathrm{R}$ plasmid carriage, chromosomal and extrachromosomal, confers definite evolutionary advantages to $H$. influenzae. Extrachromosomal $\mathrm{R}$ plasmids are efficient in disseminating resistance genes throughout the species but are easily lost in the absence of selective pressure. We previously observed that when either of two $\mathrm{Ap}^{\mathrm{R}} H$. influenzae isolates carrying $30 \times 10^{6} \mathrm{~mol}$. wt. R plasmids were inoculated into infant $M$. mulatta, the $\mathrm{Ap}^{\mathrm{R}}$ resistance determinants were quickly lost (Daum et al., 1981). Moreover, $\mathrm{Ap}^{\mathrm{R}} \mathrm{H}_{\text {. influenzae type }}$ b strains carrying $30 \times 10^{6} \mathrm{~mol}$. wt R plasmids are less efficient pathogens in the infant rat model of experimental $H$. influenzae type $\mathrm{b}$ infection than their $\mathrm{Ap}^{\mathrm{S}}$ derivates (Daum et al., 1982). These data suggest that the host may place negative selective pressure on $\operatorname{Ap}^{\mathrm{R}} H$. influenzae carrying $\mathrm{R}$ plasmids, especially those strains demonstrating instability of the $\beta$-Lac $\mathrm{La}^{+}$ phenotype. Further support for this was found among the serotype $b$ isolates from blood or CSF, none of which contained unstable $30 \times 10^{6} \mathrm{~mol}$. wt plasmid DNA. Conversely, 22 out of 27 $(81 \%)$ 'plasmid-free' type $b$ isolates were isolated from patients with systemic infections. 'Plasmid-free' $H$. influenzae with chromosomally integrated R plasmids are inefficient at the dissemination of resistance genes; however, they are uniformly stable and perpetuate resistance determinants in the $H$. influenzae gene pool. We conclude that the existence of two modes of $\mathbf{R}$ determinant carriage in $H$. influenzae confers the evolutionary advantage of high frequency $\beta$ lactamase gene dissemination while retaining phenotype immortalization.

We thank Mary Glode, Don Killelea, Mike Murray, Arnold Smith, Grace Leidy and Johan Stuy for kindly providing strains for study. Ms Deborah Swaim assisted in the preparation of the manuscript. We gratefully acknowledge the thoughtful comments and expertise of J. Craig Cohen.

\section{REFERENCES}

ALEXANDER, H. E. \& LeIDY, G. (1953). Induction of streptomycin resistance in sensitive Hemophilus influenzae by extracts containing desoxyribonucleic acid from resistant Hemophilus influenzae. Journal of Experimental Medicine 97, 17-31.

ANDERSON, P., Johnston, R. B. \& SMITH, D. H. (1972). Human serum activities against Hemophilus influenzae type b. Journal of Clinical Investigation 51, 31-38.

Bendler, J. W. III (1976). Physical size of the donor locus and transmission of Haemophilus influenzae ampicillin resistance genes by deoxyribonucleic acid-mediated transformation. Journal of Bacteriology 125, 197-204.

Broda, P. (1979). Plasmids, pp. 12-22. Oxford \& San Francisco: W. H. Freeman.

Daum, R. S., Syriopoulou, V. Ph., Smith, A. L., SCHEIFELE, D. W. \& WiLlaRD, J. E. (1981). Loss of plasmid DNA coding for $\beta$-lactamase during experimental Haemophilus influenzae infection. Journal of Infectious Diseases 143, 548-553.

DAum, R. S., ZuTter, M., Johnson, E. J. \& Willard, J. E. (1982). Pathogenic efficiency of plasmid containing ampicillin resistant $H$. influenzae type b. (Abstract 961) Pediatric Research 16, 239A.

DeGraaff, J., Elwell, L. P. \& Falkow, S. (1976).
Molecular nature of two beta-lactamase-specifying plasmids isolated from Haemophilus influenzae type b. Journal of Bacteriology 126, 439-446.

Elwell, L. P., DeGraaff, J., Seibert, D. \& Falkow, S. (1975). Plasmid-linked ampicillin resistance in Haemophilus influenzae type b. Infection and Immunity 12, 404-410.

Elwell, L. P., Saunders, J. R., Richmond, M. H. \& FALkow, S. (1977). Relationships among some $R$ plasmids found in Haemophilus influenzae. Journal of Bacteriology 131, 356-362.

FARRAR, W. E. \& O'DELL, N. (1974). Beta-lactamase activity in ampicillin-resistant Haemophilus influenzae. Antimicrobial Agents and Chemotherapy 6, 625629.

GunN, B. A., WoOdall, J. B., Jones, J. F. \& ThornsBERRY, C. (1974). Ampicillin-resistant Haemophilus influenzae. Lancet 2,845 .

HANSEN, J. B. \& OLSEN, R. H. (1978). Isolation of large bacterial plasmids and characterization of the P2 incompatibility group plasmids pMG1 and pMG5. Journal of Bacteriology 135, 227-238.

HARKESS, N. K. \& MURRAY, M. L. (1978). Restriction enzyme analysis of plasmids from Haemophilus influenzae. Antimicrobial Agents and Chemotherapy 13, 802-808. 
Hedges, R. W. \& JaCOB, A. (1974). Transposition of ampicillin resistance from RP4 to other replicons. Molecular and General Genetics 132, 31-40.

Hefrron, F., Rubens, C. \& Falkow, S. (1975a). Translocation of a plasmid DNA sequence which mediates ampicillin resistance: molecular nature and specificity of insertion. Proceedings of the National Academy of Sciences of the United States of America 72, 3623-3627.

Heffron, F., Sublett, R., Hedges, R. W., Jacob, A. \& Falkow, S. $(1975 b)$. Origin of the TEM betalactamase gene found on plasmids. Journal of Bacteriology 122, 250-256.

JahN, G., Laufs, R., Kaulfers, P. M. \& Kolenda, H. (1979). Molecular nature of two Haemophilus influenzae R-factors containing resistances and the multiple integration of drug resistance transposons. Journal of Bacteriology 138, 584-597.

LAUFS, R. \& Fock, R. (1979). Characterization of genes specifying ampicillin resistance in bacterial isolates using a single-strand specific nuclease for analysis of plasmid DNA-DNA duplexes. Journal of General Microbiology 111, 233-237.

LAufs, R. \& Kaulfers, P. M. (1977). Molecular characterization of a plasmid specifying ampicillin resistance and its relationship to other $\mathbf{R}$-factors from Haemophilus influenzae. Journal of General Microbiology 103, 277-286.

LAUfS, R., KaUlfers, P. M., JAhN, G. \& TESChNER, U. (1979). Molecular characterization of a small Haemophilus influenzae plasmid specifying $\beta$-lactamase and its relationship to $\mathrm{R}$ factors from Neisseria gonorrhoeae. Journal of General Microbiology 111, 223-231.

Medeiros, A. A. \& O'Brien, T. F. (1975). Ampicillin resistant Haemophilus influenzae type bossessing a TEM-type beta-lactamase but little permeability barrier to ampicillin. Lancet 1, 716-718.

Meyers, J. A., Sanchez, D., Elwell, L. P. \& FaLkow, S. (1976). Simple agarose gel electrophoretic method for the identification and characterization of plasmid deoxyribonucleic acid. Journal of Bacteriology 127, 1529-1537.
MoRse, S. I. (1980). The Hemophilus-Bordetella group. In Microbiology, 3rd edn, pp. 793-794. Edited by B. D. Davis and others. Hagarstown, Maryland: Harper \& Row.

Moxon, E. R., SMITH, A. L., Averill, D. R. \& SMITH, D. H. (1974). Haemophilus influenzae meningitis in infant rats after intranasal inoculation. Journal of Infectious Diseases 129, 154-162.

O'Callaghan, C. H., Morris, A., Kirby, S. M. \& SHINGLER, A. H. (1972). Novel method for detection of $\beta$-lactamase by using a chromogenic cephalosporin substrate. Antimicrobial Agents and Chemotherapy 1, 283-288.

Roberts, M. C. \& SMITH, A. L. (1980). Molecular characterization of 'plasmid-free' antibiotic resistant Haemophilus influenzae. Journal of Bacteriology 144, 476-479.

SAUNDERS, J. R. \& SYKeS, R. B. (1977). Transfer of a plasmid specified beta-lactamase gene from Haemophilus influenzae. Antimicrobial Agents and Chemotherapy 11, 339-344.

Saunders, J. R., Elwell, L. P., Falkow, S., Sykes, R. B. \& RichmoND, M. H. (1978). $\beta$-Lactamases and R-plasmids of Haemophilus influenzae. Scandinavian Journal of Infectious Diseases 13s, 16-22.

Slaney, L. \& AlBritton, W. L. (1979). Transferable antibiotic resistance in Haemophilus influenzae. (Abstract H79) 79th Annual Meeting of the American Society for Microbiology, p. 132.

StuY, J. H. (1979). Plasmid transfer in Haemophilus influenzae. Journal of Bacteriology 139, 520-529.

STUY, J. H. (1980). Chromosomally integrated conjugative plasmids are common in antibiotic-resistant Haemophilus influenzae. Journal of Bacteriology 142, 925-930.

Sykes, R. B., Matrhew, M. \& O'Callaghan, C. H. (1975). R-factor mediated $\beta$-lactamase production by Haemophilus influenzae. Journal of Medical Microbiology 8, 437-441.

Vega, R., SAdoff, H. L. \& Patterson, M. J. (1976). Mechanisms of ampicillin resistance in Haemophilus influenzae type b. Antimicrobial Agents and Chemotherapy 9, 164-168. 